\title{
Gastric Function in Children with Cystic Fibrosis: Effect of Diet on Gastric Lipase Levels and Fat Digestion
}

\author{
MARTINE ARMAND, MARGIT HAMOSH, JESSICA R. PHILPOTT, AMY KOVAR RESNIK, \\ BERYL J. ROSENSTEIN, ADA HAMOSH, JAY A. PERMAN, AND PAUL HAMOSH \\ Division of Developmental Biology and Nutrition [M.H., J.R.P.], Department of Physiology and \\ Biophysics [P.H.], Georgetown University Medical Center, Washington, DC 20007, U.S.A.; Johns Hopkins \\ Medical Center, Cystic Fibrosis Center [A.K.R., B.J.R.], and Department of Pediatrics [A.H., J.A.P.], \\ Baltimore, MD 21287, USA; and INSERM Unité 476, National Institute of Health and Medical Research, \\ Faculté de Médecine de la Timone, Marseille 13005, France [M.A.]
}

\begin{abstract}
The effect of diet, usual ( $44 \pm 4 \%$ energy as fat), high-fat (49 $\pm 4 \%$ energy as fat), and moderate-fat ( $33 \pm 2 \%$ energy as fat), on gastric function (lipase and pepsin activities, $\mathrm{pH}$, emptying rate) and intragastric digestion of fat were assessed in six children with cystic fibrosis. Fasting and postprandial activity of digestive enzymes, gastric $\mathrm{pH}$, and gastric volume measured before, during, and after $120 \mathrm{~min}$ of feeding did not differ significantly as a function of fat intake. Postprandial gastric lipase output (units per kilogram of body weight) during usual, moderate-fat, and high-fat diets was close to or higher than (38.8 $\pm 7.2,44.9 \pm 8.6$, and $54.8 \pm 5.5 \mathrm{U} / \mathrm{kg}$ per $20 \mathrm{~min}$ ) gastric lipase output of premature infants $(22.5 \pm 6.4$ to $28.3 \pm 6.6 \mathrm{U} / \mathrm{kg}$ per $20 \mathrm{~min}$ ) or of healthy adults $(5.4 \pm 0.4 \mathrm{U} / \mathrm{kg}$ per $15 \mathrm{~min})$ fed a high-fat diet. Postprandial pepsin output was higher (4749 \pm $797,6117 \pm 925$, and $5444 \pm 819 \mathrm{U} / \mathrm{kg}$ per $20 \mathrm{~min})$ than in premature infants $(597 \pm 77$ to $743 \pm 97 \mathrm{U} / \mathrm{kg}$ per $20 \mathrm{~min})$ or healthy adults $(781 \pm 56 \mathrm{U} / \mathrm{kg}$ per $15 \mathrm{~min})$. Eighty minutes after
\end{abstract}

\section{ABSTRACT}

feeding gastric lipolysis reached 20 to $36 \%$. This study shows that gastric lipase activity is high in cystic fibrosis patients maintained on diets providing $32 \%$ to $49 \%$ energy as fat, and that gastric lipase level did not increase over the ranges of dietary fat intake tested. (Pediatr Res 55: 457-465, 2004)
CF, cystic fibrosis
CFTR, CF transmembrane conductance regulator
PI, pancreatic insufficiency
TG, triglycerides
DG, diglycerides
MG, monoglycerides
PL, phospholipids
PEG, polyethylene glycol
RDA, recommended daily allowance

\section{Abbreviations}

$\mathrm{CF}$ is the most common autosomal recessive disorder in Caucasians and results in pulmonary, gastrointestinal, metabolic and nutritional disturbances (1-3). The basic defect in $\mathrm{CF}$ involves faulty regulation of the epithelial cell chloride channel caused by mutations in the CFTR gene (4). Deletion of phenylalanine at amino acid position 508 ( $\Delta$ F508) in the CFTR protein accounts for $70 \%$ of $\mathrm{CF}$ gene abnormalities in patients of Northern European ancestry (5). The $\Delta \mathrm{F} 508$ mutation leads to defective maturation of CFTR and absence of the protein at the apical membrane (6). Greater than $98 \%$ of $\Delta$ F508 homozygotes have PI.

Received May 26, 2003; accepted September 3, 2003.

Correspondence: Martine Armand, M.D., Faculte de Medecine de la Timone, INSERM Unite 476, Nutrition Humaine et Lipides, 27 Boulevard Jean Moulin, 13005 Marseille, France; e-mail: Martine.Armand@medecine.univ-mrs.fr

DOI: 10.1203/01.PDR.0000110522.78194.5B
PI, resulting in fat malabsorption, is found in at least $85 \%$ of CF patients (7-9). Lacking pancreatic enzymes, CF patients are dependent on pancreatic enzyme supplements (10-12). However, the degree to which fat is absorbed by these patients varies, and even when pancreatic lipase activity is completely absent, dietary fat is absorbed. Indeed, Ross (13) reported fat absorption of 26 to $81 \%$ in a group of children with $\mathrm{CF}$, although most of them did not have detectable pancreatic lipase activity. Lapey et al. (14) reported greater than 50\% fat absorption in 15 patients with exocrine PI secondary to $\mathrm{CF}$, without any oral enzyme supplementation. Ross and Sammons (15) have therefore postulated the presence of compensatory lipolytic activity in PI. It was shown subsequently that this compensation is provided by gastric lipase, the enzyme that initiates fat digestion in the stomach $(16,17)$. Because of lower $\mathrm{pH}$ in the upper small intestine in this condition (18-20), gastric lipase is able to act not only in the stomach but also in 
the duodenum (18-20). Indeed, gastric lipase amounted to $90 \%$ of total lipase activity delivered to the ligament of Treitz throughout a 2-h postprandial period in patients with PI secondary to CF (18) or chronic alcoholism (20). Pancreatic enzyme supplements fail frequently to normalize fat absorption in PI patients (10-12). Inactivation in the stomach and suboptimal release in the duodenum because of low $\mathrm{pH}$ are the main reasons that only as little as $8 \%$ of lipase given in coated supplements reaches the ligament of Treitz (11). Thus, gastric lipase might provide additional therapy for the prevention of steatorrhea in CF because of the characteristics of the enzyme and the specific conditions in the upper small intestine.

Because a positive correlation has been reported between good nutritional status and long-term survival and well-being in CF patients (21), numerous published recommendations for the nutritional management of children with $\mathrm{CF}$ encourage an energy-dense diet, especially a high-fat intake $(22,23)$, to counteract energy losses from malabsorption and increased energy expenditure.

The fat content of the diet affects the level of digestive lipases (24-28). Several animal studies have shown that doubling the usual fat intake leads to a $95 \%$ increase in lingual lipase levels in tongue tissue in the rat (24) and a 70\% increase in gastric lipase levels in gastric mucosa of rabbits or pigs within 1 to $2 \mathrm{wk}$ (27). In healthy adult human subjects a 50 to $70 \%$ increase in gastric lipase content occurs within $2 \mathrm{wk}$ after change of dietary fat from 25 to $50 \%$ (28).

In light of all these studies, it might be important to explore the possibility of increasing the endogenous levels of gastric lipase in CF patients. Thus, this study aimed to assess whether fat intake modulates gastric lipase level in children with $\mathrm{CF}$, i.e. whether a high-fat diet (approximately 50\% energy as fat) can induce an increase in lipase level compared with a moderate-fat diet (approximately 30\% energy as fat). In parallel, intragastric fat digestion was also studied.

\section{METHODS}

Subjects. Six children aged 2.5 to 14 y old $[6.4 \pm 1.6$ y (mean $\pm \mathrm{SD}$ ), three girls and three boys] were enrolled in the study after informed consent was given by the parents. The experimental protocol was approved by the institutional review boards of Johns Hopkins Medical Institution (Baltimore, MD,
U.S.A.) and Georgetown University Medical Center (Washington, DC, U.S.A.). The diagnosis of CF was based on clinical evaluation. PI was documented by abnormal quantitative fecal fat in all patients. All children had evidence of pulmonary disease, and their Taussig clinical score ranged from 50 to 95 (29). Individual clinical data on the patients are presented in Table 1. Growth characteristics and anthropometric data were in the ranges of data previously published for CF patients (30). Four children were $\Delta \mathrm{F} 508$ homozygotes, one $\Delta \mathrm{F} 508$ /unknown, and one G542X/2814 delA genotype. All patients had gastrostomy feeding tubes, and all but patient 2 were receiving enteral feeds during the period of the study. Patients were studied as outpatients. All patients were treated with pancreatic enzyme supplements: three with Pancrease (Ortho McNeil Pharmaceuticals, Raritan, NJ, U.S.A.), two with Creon (Solvay Pharmaceuticals, Marietta, GA, U.S.A.), and one with Ultrase (Scandi Pharmaceuticals, Birmingham, AL, U.S.A.). No medication that could interfere with gastrointestinal function and no enzyme supplements were used on the days of the study. Each child served as his or her own control.

CFTR mutation detection. Mutation detection was performed using reverse dot-blot technology and reagents and methods supplied by the manufacturers (Perkin-Elmer, Norwalk, CT, U.S.A.). One patient had her second mutation (2814delA) identified by Genzyme (Framingham, MA, U.S.A.).

Diets and test meals. All patients were regularly followed by a dietitian [A.K.] and advised to eat an energy-dense diet. The usual diet and nutritional habits of each subject were determined using a 3-d diet record. Dietary analyses were done using the Nutritionist III software (Oregon, U.S.A.).

The patients were studied at three different periods: first during their usual diet, then $2 \mathrm{wk}$ after consuming a moderatefat diet (approximately $30 \%$ of calories derived from fat), and finally 2 wk after consuming a high-fat diet (approximately $50 \%$ of calories derived from fat). The diets were given in random order. The experimental diets (moderate and high-fat diets) were calculated in accordance with the regular energy intake of the subjects $(2122 \pm 210 \mathrm{kcal} / \mathrm{d})$. The diets during the experimental periods were evaluated by a 3-d dietary survey.

The two test meals were similar to the experimental diets and contained a similar amount of protein. The moderate-fat

Table 1. Anthropometric and clinical data of the study CF children

\begin{tabular}{|c|c|c|c|c|c|c|}
\hline Patients & 1 & 2 & 3 & 4 & 5 & 6 \\
\hline Age (y) & 2.4 & 4.5 & 5.0 & 5.5 & 7.0 & 14.0 \\
\hline Height $(\mathrm{cm})^{*}$ & $89.8(25-50)$ & $96.5(3)$ & $104.4(10-25)$ & $115.7(75)$ & $109.4(<3)$ & $154.4(10-25)$ \\
\hline Weight $(\mathrm{kg})^{*}$ & $12.9(25-50)$ & $15.6(10)$ & $16.8(25-50)$ & $17.7(25)$ & $17.2(<3)$ & $42.0(5-10)$ \\
\hline Taussig score & 95 & 85 & 71 & 50 & 45 & 68 \\
\hline $\mathrm{AC}(\mathrm{cm})$ & 16.7 & 17.0 & 15.6 & 16.0 & 16.3 & 24.0 \\
\hline TSF (mm) & 7.2 & 5.5 & 3.5 & 3.0 & 5.5 & 13.0 \\
\hline Age at diagnosis & $7 \mathrm{mo}$ & $4 \mathrm{mo}$ & $1 \mathrm{wk}$ & $5 \mathrm{mo}$ & $4 \mathrm{mo}$ & $13 \mathrm{mo}$ \\
\hline CF genotype & $\Delta \mathrm{F} 508 / \mathrm{ukn}$ & $\Delta \mathrm{F} 508 / \Delta \mathrm{F} 508$ & $\Delta \mathrm{F} 508 / \Delta \mathrm{F} 508$ & $\Delta \mathrm{F} 508 / \Delta \mathrm{F} 508$ & $\Delta \mathrm{F} 508 / \Delta \mathrm{F} 508$ & G542X/2814delA \\
\hline
\end{tabular}

* Number in parentheses indicate percentiles for each patient.

Abbreviations: AC, arm circumference; TSF, triceps skin fold; MAMA, mid-arm muscle area; AFA, arm fat area; ukn, unknown. 
test meal consisted of $240 \mathrm{~mL}$ of vanilla Ensure formula containing $8.8 \mathrm{~g}$ protein, $34.4 \mathrm{~g}$ carbohydrate, and $8.8 \mathrm{~g}$ fat and provided $252 \mathrm{kcal}, 14 \%$ protein, $54.5 \%$ carbohydrate, and $31.4 \%$ fat (Mead Johnson Nutritionals, Evansville, IL, U.S.A.). The high-fat test meal was composed of $138 \mathrm{~mL}$ Ensure, 4 teaspoons of protein powder (Promod, Ross Products Division, Abbott Laboratories, Columbus, OH, U.S.A.), and $11 \mathrm{~mL}$ of corn oil and water (final volume $240 \mathrm{~mL}$ ) and provided 267 kcal, $16 \%$ protein, $30 \%$ carbohydrate, and $54 \%$ fat. As the size of the fat droplets affects lipase activity $(31,32)$, the high-fat test meal was mixed in a blender for $10 \mathrm{~min}$. The Ensure formula fat droplet size was $0.52 \pm 0.03 \mu \mathrm{m}$, and the high-fat test meal fat droplet size was $0.77 \pm 0.12 \mu \mathrm{m}$; the specific surface area of the emulsions was $17.4 \pm 1.1$ and $11.8 \pm 2.4$ $\mathrm{m}^{2} / \mathrm{g}$ of lipid, respectively.

Collection of gastric contents. At the completion of $2 \mathrm{wk}$ on each diet the patients were studied at $0800-0900 \mathrm{~h}$ after a 9-h fast. Fasting gastric aspirates were collected at 10-min intervals for a period of $30 \mathrm{~min}$ through a gastrostomy tube (Bard International Products, Billerica, MA, U.S.A.). Then, a standardized liquid test meal containing PEG-4000, a nonabsorbable marker (50 mg PEG/test meal), was administered directly into the stomach through the gastrostomy tube for a period of $10 \mathrm{~min}$. The high-fat test meal was used after the usual and the high-fat diet periods, and the moderate-fat test meal after the moderate-fat diet period. Postprandial gastric specimens (6 to 7 $\mathrm{mL}$ ) were sampled at 20-min intervals, timed from the time when half of the meal volume was fed, for an overall sampling period of 80 to $120 \mathrm{~min}$ depending on the patient. Gastric samples were withdrawn by a syringe after careful mixing by repeated manual aspiration-reinstillation to ensure that representative samples were obtained. Immediately after collection of each sample, the appearance was recorded, the $\mathrm{pH}$ was measured using a portable $\mathrm{pH}$ meter (model 840008 CMS; Spree Scientific, Houston, TX, U.S.A.), and the sample was neutralized to $\mathrm{pH} 4.5-5.0$, when necessary, to prevent the inactivation of gastric lipase. Neutralization did not interfere with pepsin activity because this enzyme is stable when stored at $\mathrm{pH} 1$ to 5 . A cocktail of inhibitors $(33,34)(10 \% \mathrm{vol} / \mathrm{vol})$ was added to the sample aliquot taken for neutral lipid analysis to prevent lipolysis during storage. Under these conditions, approximately 85 to $90 \%$ of gastric lipase activity is inhibited (34).

All specimens were collected on ice, and then kept in dry ice until transfer to the laboratory. All specimens were stored at $-70^{\circ} \mathrm{C}$ until assay. Under these storage conditions, lipase activity is stable for months $(35,36)$.

Measurement of gastric content volume. We used the double-sampling marker dilution method of George (37), using PEG-4000 as a marker, to measure gastric volume to quantify total gastric lipase activity level, and to compare gastric emptying rate between both test meals. The meals used were fully homogenized liquid test meals that have been shown to lead to simultaneous emptying of the aqueous and lipid phases (38, 39). Thus, under these conditions, PEG-4000, similar to phenol red (35), is a marker of the aqueous phase and can be used to monitor the emptying of all the meal components (32). A small amount of concentrated PEG marker was added $(1 \mathrm{~mL}$, con- taining $50 \mathrm{mg}$ of PEG) at each collection time after a sample was collected just before addition of a new dose of marker. Volumes present in the stomach (secretion plus emulsion) were calculated by the following equation:

$$
V_{1}=V_{2} \frac{\left(C_{2}-C_{3}\right)}{\left(C_{3}-C_{1}\right)}
$$

where $V_{1}$ is the volume to be determined; $C_{1}$ the initial concentration of marker in $V_{1} ; V_{2}$ the volume of concentrated marker added to $V_{1} ; C_{2}$ the concentration of added marker; $C_{3}$ the final concentration of the marker; the mass of marker in $V_{1}$ is given by $V_{1} \times C_{1}$; and the mass of marker in $V_{2}$ is given by $V_{2} \times C_{2}$.

Sampling was taken into account when determining the final volume. The amount of fat present in the stomach contents was calculated by multiplying the gastric volume by the fat concentration at each time. Rates of fat emptying were thus calculated knowing the initial quantity of fat ingested ( 8.8 or $16 \mathrm{~g}$ ) and the total amount of fat present in the stomach at each time.

Quantification of gastric lipase activity. Gastric lipase activity in the aspirates was quantified using a stable emulsion of tri $\left[{ }^{3} \mathrm{H}\right]$ olein as previously described $(28,40)$. The $\left[{ }^{3} \mathrm{H}\right]$ oleic acid produced was quantified after separation by liquid-liquid partition (41). One lipase unit is expressed as the release of 1 $\mu \mathrm{mol}$ of FFA per minute (international unit). Gastric lipase output (concentration times volume) is expressed as units per kilogram of body weight.

Because it was previously reported that PEG in the range of $1-5 \mathrm{mg} / \mathrm{mL}$ inhibits pancreatic lipase activity (42), we have tested the effect of PEG-4000 on gastric lipase and pepsin using human gastric juice. The results showed no effect of PEG when present at the above concentrations (data not shown).

Quantification of pepsin activity. Pepsin activity was measured in $20-40 \mu \mathrm{L}$ of gastric aspirates $(43,44)$ as previously described $(28,40)$. One pepsin unit is defined as the amount of enzyme required to produce $0.1 \mu \mathrm{mol}$ of tyrosine-containing peptides at $37^{\circ} \mathrm{C}$ in $10 \mathrm{~min}$ at $\mathrm{pH} 1.8$ from a $2 \% \mathrm{Hb}$ solution. Pepsin output (concentration times volume) is expressed as units per kilogram of body weight.

Lipid analysis. Lipids in test meals and gastric aspirates were homogenized and extracted in chloroform-methanol (2:1, $\mathrm{vol} / \mathrm{vol}$ ), containing $0.01 \%$ BHT according to Folch et al. (45). To ensure complete protonation of fatty acids, the organic solvent phases were partitioned with $20 \%$ ( $\mathrm{vol} / \mathrm{vol}) 0.15 \mathrm{M}$ aqueous $\mathrm{NaCl}$ containing $2 \%$ glacial acetic acid (vol/vol, $\mathrm{pH}$ 3.0) as previously described (33).

Neutral lipid classes (triacylglycerol, diacylglycerol, monoacylglycerol, FFA) were separated by two-stage, onedimensional thin-layer chromatography according to Bitman and Wood (46) and stained in 10\% copper sulfate- $8 \%$ phosphoric acid (wt/vol) solution. Lipid was quantified by densitometry with a Shimadzu dual-wavelength densitometer (deuterium lamp, $340 \mathrm{~nm}$; Shimadzu Scientific Instruments, Columbia, MD, U.S.A.). The densitometric areas were fitted by computer to a linear regression model, and the coefficient of determination, $r^{2}$, was in the range of $0.90-0.98$. A standard 
sample $(5-20 \mu \mathrm{g})$ was included in every experimental plate to correct for deviations from the standard calibration curve. Values were converted into moles using average molecular masses calculated according to the fatty acid composition of the test meals $(\mathrm{TG}=872 ; \mathrm{DG}=612 ; \mathrm{MG}=352 ; \mathrm{FFA}=$ 278).

The extent of gastric TG hydrolysis was calculated as the percent of TG disappearance from total glycerides present (TG $+\mathrm{DG}+\mathrm{MG} ; \% \mathrm{TG}$ total) and from the percentage of $\mathrm{TG}$ originally present in the test meals (\%TG at time 0$)$, i.e. TG disappearance $(\%)=\% \mathrm{TG}$ time $0-\% \mathrm{TG}$ total, as previously described $(32,34,40)$.

PEG determination. PEG concentration in gastric contents was determined according to the method of Hyden (47) as modified by Ulyatt (48).

Statistical analysis. Data are given as mean \pm SEM of six or four subjects. Data were tested by two-way ANOVA for paired values using the statistical package (StatView 512+) for the Macintosh. Significance level was set at $p<0.05$ for any variable tested (49).

\section{RESULTS}

This study determined whether gastric function assessed as $\mathrm{pH}$, gastric emptying, digestive enzyme activity, and intragastric lipolysis is modulated by the amount of fat in the diets given to children with CF.

Composition of regular and experimental diets. Nutrient intake data are shown in Table 2. Energy provided by fat ranged between 35 and $60 \%$ of the total energy supply in the usual diet, and the fat consumption was 65 to $148 \mathrm{~g}$ of fat per day (3.5 to $8.8 \mathrm{~g}$ fat $/ \mathrm{kg}$ ). During the moderate-fat period, fat ranged between 27.9 and $37.9 \%$ of the total energy, and daily intake of fat was 33 to $82 \mathrm{~g}$ ( 2 to $4 \mathrm{~g} / \mathrm{kg}$ per day). During the high-fat diet period 43 to $62 \%$ of energy was provided by fat with a daily fat intake of 83 to $148 \mathrm{~g} / \mathrm{d}$, representing 3.5 to 8.8 $\mathrm{g} / \mathrm{kg}$ per day. Caloric intake was lower in the moderate-fat diet; however, protein intake was relatively close in the three diets (70-76 g/d).

Gastric pH throughout digestion. Gastric $\mathrm{pH}$ during the usual, high-fat, and moderate-fat diet periods is shown in Figure 1. During the usual diet, the $\mathrm{pH}$ values varied between 1.5 and 3.0 in fasting conditions, increased to $4.5-5.9$ immediately after a meal was ingested, and then gradually decreased postprandially to $2.0-4.6$ at $1 \mathrm{~h}$ and to $1.6-3.1$ at $2 \mathrm{~h}$. During moderate-fat and high-fat diets, $\mathrm{pH}$ values varied between 1.73 and 2.03 and 1.87 and 2.05 at baseline, respectively, then increased to 5.4-5.5 after the test meals, and gradually de-
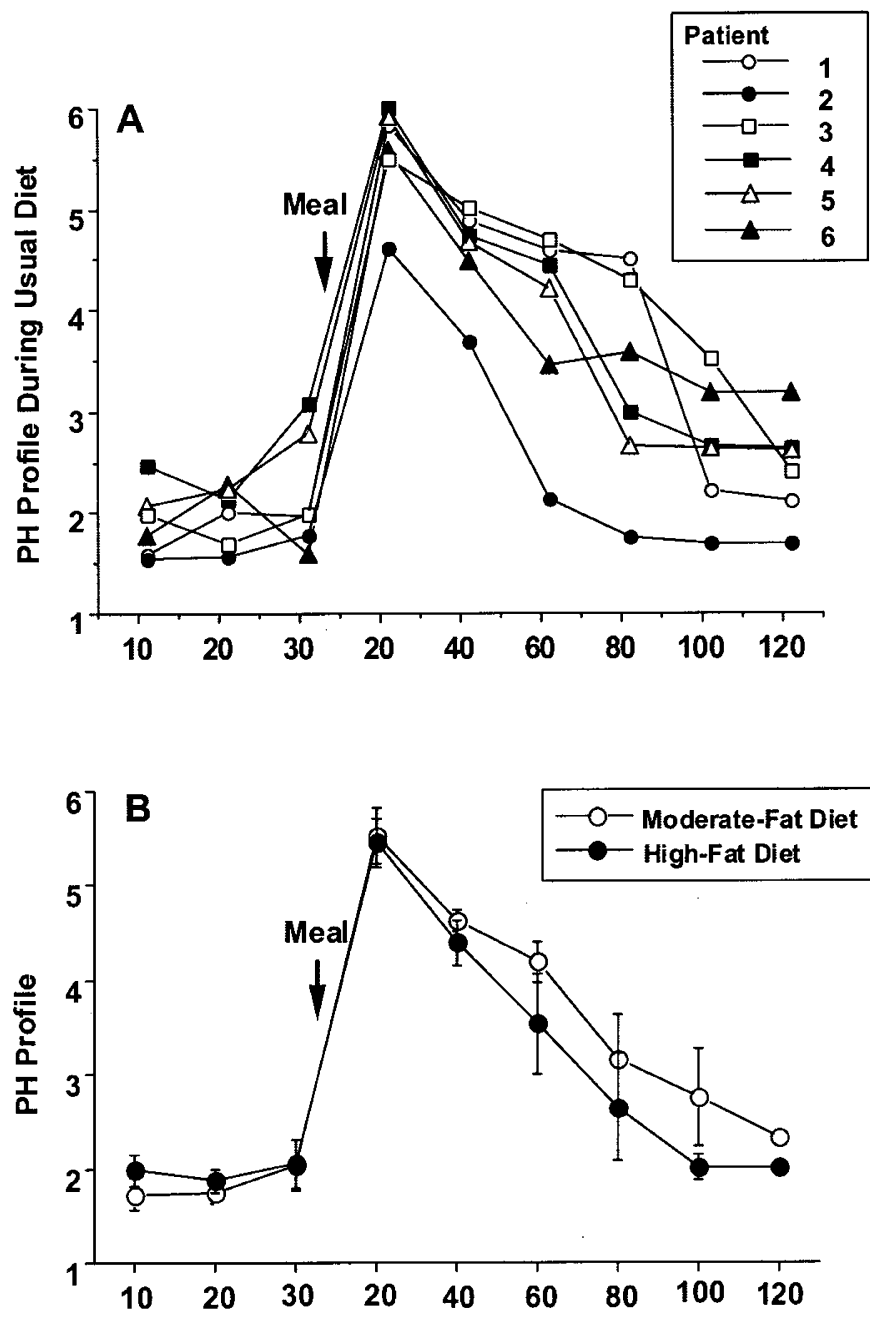

Time (min)

Figure 1. $\mathrm{pH}$ of gastric aspirates in children with $\mathrm{CF}$ during usual diet $(A$; individual data) and during a moderate-fat $(O)$ or a high-fat $(\bullet) \operatorname{diet}(B$; data are mean \pm SEM of four subjects). The $\mathrm{pH}$ of gastric aspirates was measured at 10 -min intervals for $30 \mathrm{~min}$ during fasting conditions and at 20-min intervals for $120 \mathrm{~min}$ after gastric feeding of a test meal of $267 \mathrm{kcal}$ containing $16 \%$ protein, $30 \%$ carbohydrate, $54 \%$ fat for the regular and the high-fat diet periods, and of a test meal of $252 \mathrm{kcal}$ containing $14 \%$ protein, $54.5 \%$ carbohydrate, $31.4 \%$ fat for the moderate-fat diet period.

creased to $3.54-4.19$ after $1 \mathrm{~h}$ and to $2.02-2.33$ after $2 \mathrm{~h}$. The $\mathrm{pH}$ values appear to be slightly lower during the high-fat diet compared with the moderate-fat diet starting at $60 \mathrm{~min}$ after feeding the test meal, but the differences were not statistically significant.

Table 2. Diet composition and fat intake

\begin{tabular}{lccc}
\hline \multicolumn{1}{c}{ Components } & Usual diet* & High-fat diet† & Moderate-fat diet $\dagger$ \\
\hline Protein $(\mathrm{kcal} \%)$ & $14.1 \pm 0.9(11.1-17.5)$ & $14.0 \pm 1.3(12.0-17.8)$ & $18.0 \pm 1.2(15.1-20.4)$ \\
Carbohydrate $(\mathrm{kcal} \%)$ & $43.2 \pm 2.9(29.7-49.0)$ & $38.2 \pm 3.7(27.4-43.6)$ & $50.2 \pm 3.2(42.3-58.1)$ \\
Fat $(\mathrm{kcal} \%)$ & $43.8 \pm 3.6(35.3-60.0)$ & $48.8 \pm 4.5(43.2-62.2)$ & $32.7 \pm 2.1(27.9-37.9)$ \\
Energy $(\mathrm{kcal} / \mathrm{d})$ & $2122 \pm 210(1653-3068)$ & $2179 \pm 316(1740-3068)$ & $1561 \pm 275(1076-2315)$ \\
Fat $(\mathrm{g} / \mathrm{d})$ & $104 \pm 14(65-148)$ & $116 \pm 13(83-148)$ & $57 \pm 11(33-82)$ \\
Fat $\left(\mathrm{g} \cdot \mathrm{kg}^{-1} \cdot \mathrm{d}^{-1}\right)$ & $5.6 \pm 0.9(3.5-8.8)$ & $6.1 \pm 1.1(3.5-8.8)$ & $2.9 \pm 0.4(2.0-4.0)$ \\
\hline
\end{tabular}

Data are mean \pm SEM and ranges (parentheses) from six $(*)$ or four $(\dagger) \mathrm{CF}$ children. 
Gastric volume and fat emptying rate. Gastric emptying during the moderate-fat or high-fat diets had a similar biphasic pattern. Emptying rate was rapid during the first $40 \mathrm{~min}$ after feeding and then decreased thereafter (Fig. 2A). The time required for the volume in the stomach to decrease by half was 34 and 36 min with the moderate-fat and the high-fat diets, respectively. Gastric emptying of fat was similar throughout 120 min of digestion, although the emptying rate tended to be faster (not significantly) with the high-fat test meal (Fig. $2 B$ ). During moderate-fat and high-fat diets 59.7 and $74.8 \%$ of fat had left the stomach $1 \mathrm{~h}$ after feeding and 93.9 and $95.2 \%$ after $2 \mathrm{~h}$, respectively. Emptying rates of the test meal were similar during the usual diet to those seen with the high-fat diet (data not shown).

Gastric lipase and pepsin activity throughout digestion. Basal and after feeding activities (units per milliliter) and output of gastric lipase (expressed as units per kilogram of body weight) were similar during the moderate-fat and high-fat diet periods (Fig. 3). Basal and postprandial pepsin concentrations and output were similar irrespective of whether the children were fed high-fat or moderate-fat diets (Fig. 4). Enzyme activity (units per milliliter or total units per kilogram of body weight) did not differ during the usual diet (Table 3),
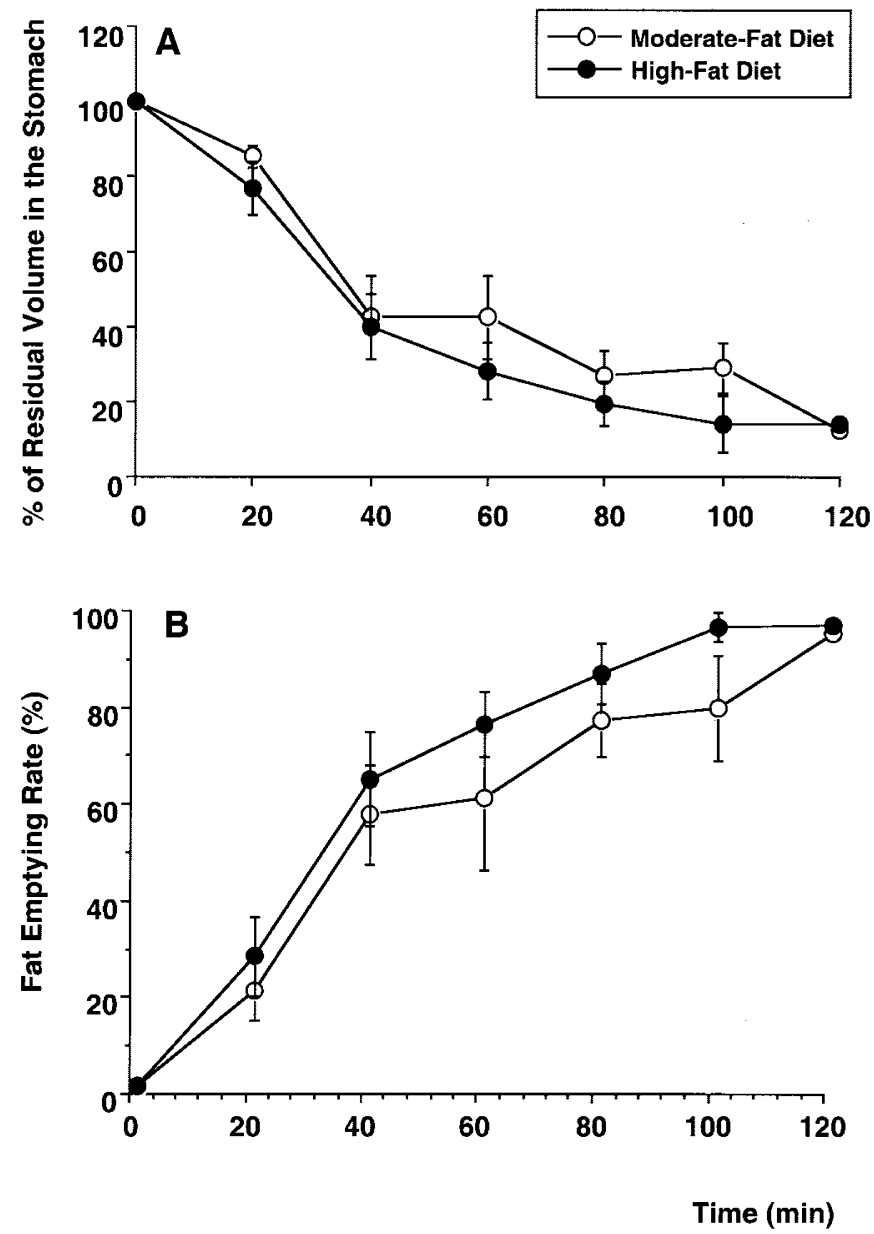

Figure 2. Effect of moderate-fat $(O)$ or high-fat $(\bullet)$ diet on gastric volume $(A)$ and fat emptying rates in the stomach $(B)$. Data are mean \pm SEM of four children with $\mathrm{CF}$.
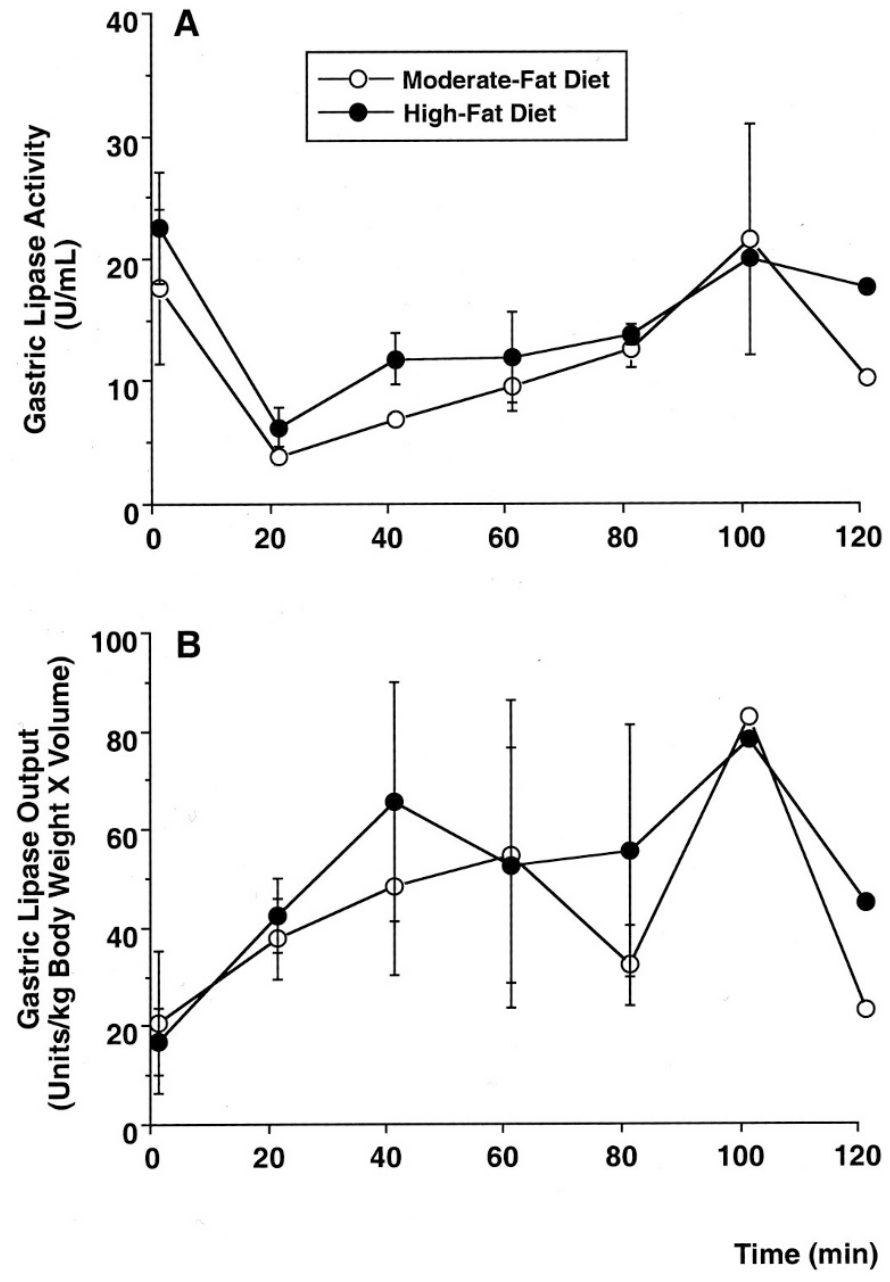

Figure 3. Effect of moderate-fat $(O)$ or high-fat $(0)$ diet on gastric lipase activity $(A)$ and gastric lipase output $(B)$ at baseline conditions (time 0$)$ and during 120 min after feeding. Data are mean \pm SEM of four children with CF.

and no relationship between activity and fat intake (3.5-8.8 g fat $/ \mathrm{kg}$ per day) was observed.

Fat digestion in the stomach. As the stomach was almost empty $100 \mathrm{~min}$ after feeding (78-95\% of the fat in the test meals had left the stomach), lipid analysis is presented until 80 min after feeding (Table 4). TG concentrations decreased, and the products of lipolysis, FFA, and DG increased throughout digestion. Production of DG rather than MG is owing to the stereoselectivity of gastric lipase (50). Gastric lipolysis, expressed as percentage decrease from initial TG minus percentage TG in the stomach at each sampling time, increased linearly for both diets until $40 \mathrm{~min}$ of digestion and then started to level off. Lipolysis rates 80 min after feeding were 36 and $20 \%$ during the moderate-fat and high-fat diets, respectively (Fig. 5). The extent of lipolysis during the usual diet (9.1 \pm $1.2 \%, 19.1 \pm 0.5 \%, 20.3 \pm 3.1 \%$, and $25.0 \pm 3.8 \%$ at 20,40 , 60 , and $80 \mathrm{~min}$ of digestion, respectively) was close to the values obtained during the high-fat diet.

\section{DISCUSSION}

Current dietary practice for patients with $\mathrm{CF}$ is to advocate energy-dense foods to maximize growth potential and improve 

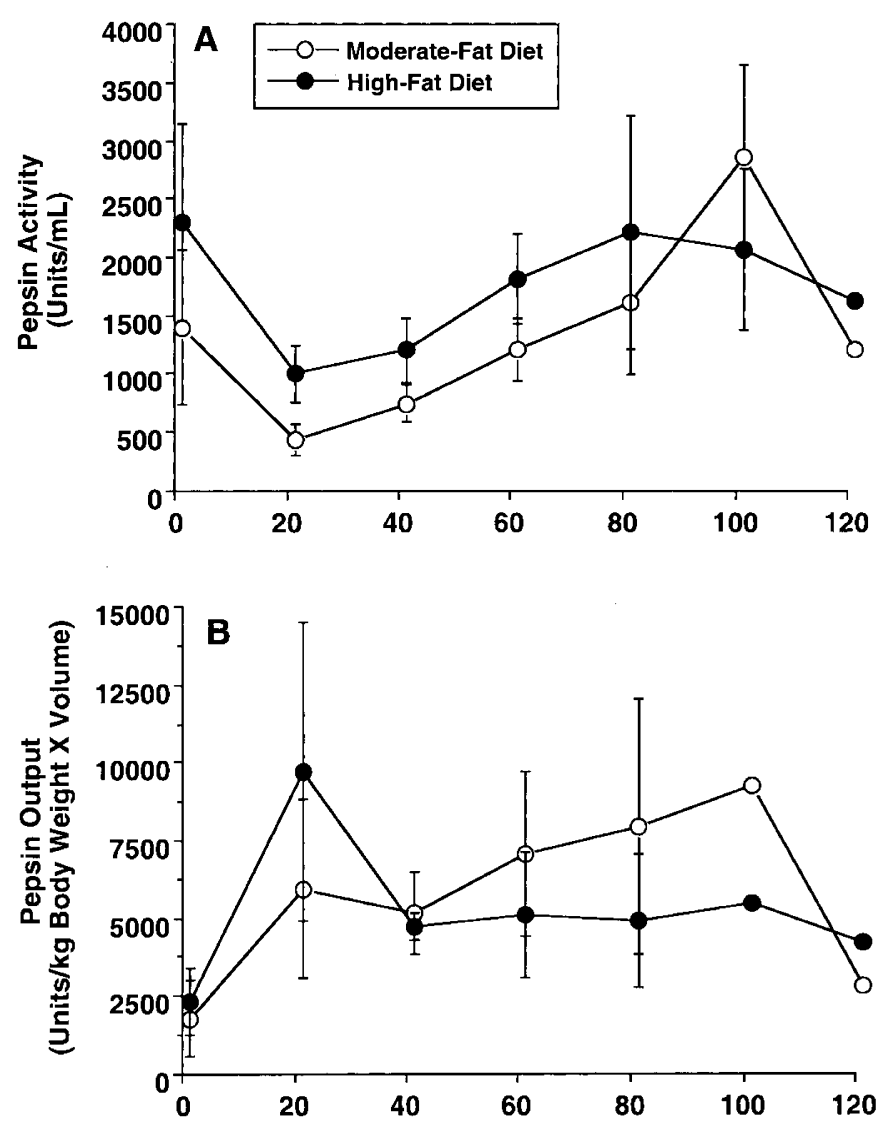

Time (min)

Figure 4. Effect of moderate-fat $(O)$ or high-fat $(O)$ diet on pepsin activity $(A)$ and pepsin output $(B)$ at baseline (time 0$)$ and during 120 min after feeding. Data are mean \pm SEM of four children with $\mathrm{CF}$.

pulmonary function (21-23). Because of exocrine PI, CF patients depend on pancreatic enzyme supplements. However, the use of high doses of pancreatic enzymes does not always normalize fat absorption and may lead to fibrosing colonopathy (51). This led to an interest in increasing the level of gastric lipase (the only endogenous digestive lipase not affected by $\mathrm{CF}$ ) by nutritional adaptation as previously reported in animals (24-27) and in healthy adults (28).

Since the early 1980 s, patients with CF have been encouraged to consume a diet, which provides $120-150 \%$ of the normal RDA for energy for age $(22,23)$. This high-energy intake can be achieved by the use of oral supplements in addition to the three principal meals. A high intake of fat is encouraged and should provide $40 \%$ of total energy intake (23). A high protein intake is also recommended, i.e. $15-20 \%$ of total daily caloric intake from protein as long as a highenergy intake is obtained (23). The children in this study on the usual diet consumed $110 \pm 6 \%$ of the RDA for energy and a high-fat diet ( $44 \pm 4 \%$ of energy) that covers $163 \pm 20 \%$ of the RDA for fat. During the high-fat diet $113 \pm 8 \%$ of the RDA for energy and $176 \pm 13 \%$ of the RDA for fat was achieved, and the moderate-fat diet provided $78 \pm 8 \%$ of the RDA for energy and $73 \pm 10 \%$ for fat. These data are in agreement with previous reports on the dietary intake of children with $\mathrm{CF}(23,52-55)$ showing that, in practice, few $\mathrm{CF}$ patients consume more than the RDA for age. Furthermore it is difficult for CF patients to maintain a high-energy intake, despite nutritional counseling, when dietary fat is restricted (56). Protein consumption was in the recommended range (23) and close to values previously reported $(54,55)$.

In our study, CF basal and postprandial levels of gastric lipase and pepsin activity were higher when compared with those in normal subjects consuming a low-fat $(23 \%$ of energy as fat) or a high-fat ( $53 \%$ of energy as fat) diet (28). In the study by Armand et al. (28), gastric lipase activity was $5.7 \pm$ 0.5 or $9.9 \pm 1.5 \mathrm{U} / \mathrm{mL}$ at baseline and $5.2 \pm 1.3$ or $7.5 \pm 1.5$ $\mathrm{U} / \mathrm{mL}$ after hormonal stimulation during a low-fat or a high-fat diet, respectively (28). In CF patients, gastric lipase activity averaged $17.0 \pm 6.3$ or $21.9 \pm 4.5 \mathrm{U} / \mathrm{mL}$ at baseline and 10.1

Table 3. Gastric enzyme activity and output in CF children during usual diet

\begin{tabular}{|c|c|c|c|c|c|c|}
\hline \multirow{2}{*}{$\begin{array}{l}\text { Patient } \\
\text { number }\end{array}$} & \multicolumn{2}{|c|}{ Enzyme concentration $(\mathrm{U} / \mathrm{mL})$} & \multicolumn{2}{|c|}{ Enzymes output (total U/kg) } & \multicolumn{2}{|c|}{ Fat consumption } \\
\hline & Gastric lipase* & Pepsin* & Gastric lipase* & Pepsin* & $\%$ Fat & Fat intake $\left(\mathrm{g} \cdot \mathrm{kg}^{-1} \cdot \mathrm{d}^{-1}\right)$ \\
\hline 1 & $13.06 \pm 2.18$ & $1034 \pm 189$ & $72.8 \pm 8.0$ & $5659 \pm 637$ & 46.5 & 8.8 \\
\hline 2 & $10.64 \pm 0.83$ & $1058 \pm 105$ & $26.1 \pm 8.1$ & $2442 \pm 635$ & 37.5 & 4.5 \\
\hline 3 & $12.57 \pm 2.07$ & $1558 \pm 250$ & $41.3 \pm 8.1$ & $4884 \pm 915$ & 35.4 & 3.9 \\
\hline 4 & $6.83 \pm 0.20$ & $639 \pm 104$ & $36.44 \pm 2.7$ & $4258 \pm 2405$ & 60.0 & 8.0 \\
\hline 5 & $11.94 \pm 3.02$ & $1519 \pm 456$ & $28.6 \pm 3.6$ & $7984 \pm 2478$ & 39.9 & 5.2 \\
\hline 6 & $13.33 \pm 4.30$ & $1519 \pm 456$ & $27.5 \pm 8.6$ & $3269 \pm 1015$ & 43.4 & 3.5 \\
\hline
\end{tabular}

* Data represent average values for a 20 -min period obtained after a high-fat test meal during 120 min of digestion.

Table 4. Fat content in the stomach ( $\mathrm{mM})$

\begin{tabular}{|c|c|c|c|c|c|c|}
\hline \multirow[b]{2}{*}{ Time (min) } & \multicolumn{3}{|c|}{ Moderate-fat diet } & \multicolumn{3}{|c|}{ High-fat diet } \\
\hline & FFA & DG & TG & FFA & DG & TG \\
\hline 20 & $7.3 \pm 2.1$ & $5.5 \pm 1.1$ & $35.5 \pm 7.0^{*}$ & $12.4 \pm 2.8$ & $10.2 \pm 1.3$ & $55.6 \pm 3.5$ \\
\hline 60 & $19.8 \pm 4.5$ & $10.0 \pm 2.4$ & $21.4 \pm 5.7^{*}$ & $24.9 \pm 5.6$ & $14.6 \pm 3.0$ & $49.9 \pm 8.0$ \\
\hline 80 & $27.3 \pm 6.0$ & $11.3 \pm 3.4$ & $17.8 \pm 6.0$ & $26.7 \pm 12.4$ & $12.8 \pm 5.5$ & $34.7 \pm 7.9$ \\
\hline
\end{tabular}

Data are mean \pm SEM of four CF children. * Indicates significant differences between diets for a lipid class and at a given time (ANOVA for paired values, $p<0.05)$. MG was only present during the high-fat diet at $80 \mathrm{~min}$ after feeding $(1.8 \pm 1.1)$. 


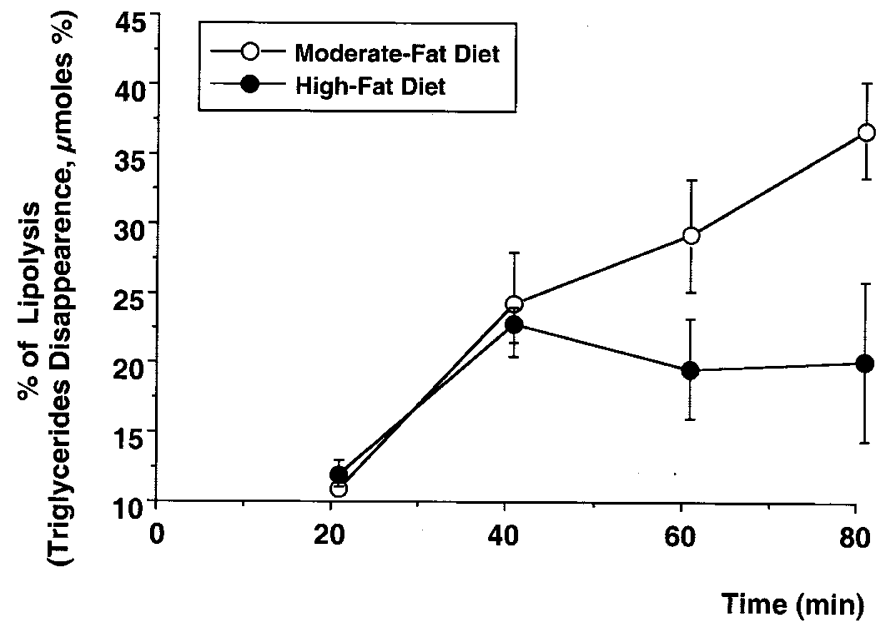

Figure 5. Lipolysis in the stomach after feeding moderate-fat $(\circ)$ or high-fat (O) diet. A moderate-fat or a high-fat test meal, respectively, was fed to each diet group, and fat digestion was quantified during $80 \mathrm{~min}$ after feeding. Data are mean $\pm \mathrm{SEM}$ of four children with $\mathrm{CF}$.

\pm 2.3 or $12.9 \pm 1.4 \mathrm{U} / \mathrm{mL}$ postprandially after the moderatefat or the high-fat diet, respectively. In healthy adults, pepsin activity averaged $942 \pm 120$ or $1333 \pm 115 \mathrm{U} / \mathrm{mL}$ at baseline and $718 \pm 147$ or $1042 \pm 204 \mathrm{U} / \mathrm{mL}$ after stimulation during low-fat or high-fat diets, respectively (28). In the CF patients, pepsin activity averaged $1335 \pm 668$ or $2242 \pm 838 \mathrm{U} / \mathrm{mL}$ under basal conditions and $1279 \pm 328$ or $1591 \pm 432 \mathrm{U} / \mathrm{mL}$ postprandially after the moderate-fat or the high-fat diet, respectively. Thus, gastric lipase activity was 1.7 to 3.0 times higher than in healthy subjects, similar to data reported by Balasubramanian et al. (57), and the pepsin activity was 1.4- to 1.8-fold higher. Because of similarities in the techniques used, comparisons can also be made with the values obtained in other cases of PI on a high-fat diet, such as premature babies (40). Thus, it appears that in CF patients gastric lipase activity is close to or sometimes even higher than in premature infants, as gastric lipase activity was $9.1 \pm 0.7 \mathrm{U} / \mathrm{mL}$ at baseline and 3.3 $\pm 0.2 \mathrm{U} / \mathrm{mL}$ after feeding for the premature infants $(40)$. The pepsin profile was quite different, i.e. much lower activity in premature infants than in $\mathrm{CF}$, with $183 \pm 16 \mathrm{U} / \mathrm{mL}$ at baseline and $92 \pm 4 \mathrm{U} / \mathrm{mL}$ after feeding. This may be related to the low pepsinogen secretion in premature infants compared with fullterm infants $(58,59)$. Gastric enzyme activity expressed as units per milliliter is dependent on the volume of gastric secretions and on dilution by the test meal; therefore, comparison of enzyme output (expressed as total units per kilogram body weight) is more pertinent (Table 5). In summary of Table 5 and taking into account the difference in collection timing, gastric lipase output was at least seven- to 20-fold higher in our CF patients compared with healthy subjects (28) and approximately 2.5-fold higher compared with premature infants (40). Pepsin output was approximately five- to eightfold or eight- to 17-fold higher in CF versus healthy adults or premature infants, respectively.

Inasmuch as gastric lipase and pepsin are secreted at high rates in CF patients, we were looking for a relationship between enzyme secretion and fat consumption. In fact, no correlation was found between daily fat intake (grams per kilogram of body weight) and gastric lipase or pepsin activity (units per milliliter or output). This is probably because of the nutritional adaptation of these enzymes as observed in healthy adult humans: activity increased when daily fat intake increased from 0.71 to $2.03 \mathrm{~g} / \mathrm{kg}$ of body weight (28). In fact, the daily fat intake in CF patients was within the range of 2.0 to 8.8 $\mathrm{g} / \mathrm{kg}$ of body weight. This finding agrees with earlier studies in animals showing that gastric lipase levels increased rapidly after a moderate increase of fat in the diet and did not increase further with additional increments in the amount of dietary fat $(25,26)$. The data suggest that it might be impossible to increase endogenous gastric lipase activity in CF patients who consume more than $2 \mathrm{~g}$ fat $/ \mathrm{kg}$ of body weight per day, because at this fat intake the nutritional adaptation of the lipase is already maximal. In light of these data, we suggest that the reason for different levels of gastric lipase activity [similar (18, $60)$, higher $(57,61)$ or lower $(62)]$ in CF patients compared with controls might be related to differences in fat consumption in the different patient populations $(23,52,55,63)$.

Furthermore, our study shows that gastric function is normal in children with $\mathrm{CF}$. The $\mathrm{pH}$ profiles at baseline and after feeding were similar to values reported for CF patients $(57,60$, 64) and for healthy adults (32). Gastric emptying rates were normal and similar to earlier reports for these types of test

Table 5. Gastric enzyme output in healthy adults, CF children, and premature infants during low-fat and high-fat diets

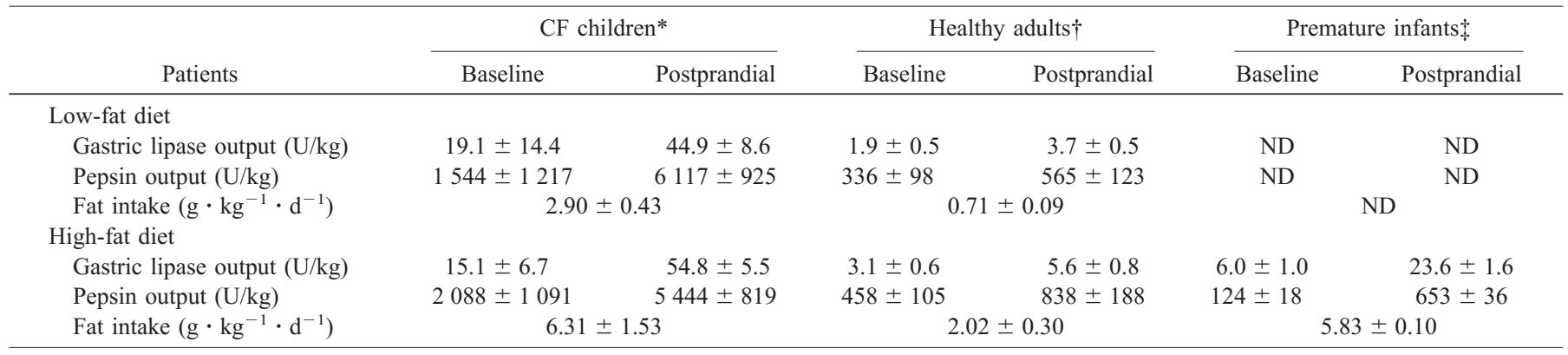

Outputs are expressed as average of total units $/ \mathrm{kg} / 10$-min collection time for baseline and as average of total units $/ \mathrm{kg} / 20-\mathrm{min}$ collection time after administration of a moderate-fat or a high-fat test meal during $120 \mathrm{~min}$ of digestion.

* Outputs are expressed as average of total units $/ \mathrm{kg} / 15$-min collection time in baseline and posprandially under pentagastrin stimulation. Weight was $61.3 \pm$ $4.7 \mathrm{~kg}$ during the low-fat diet and $61.4 \pm 4.7 \mathrm{~kg}$ during the high-fat diet 28 .

$\ddagger$ Outputs are expressed as average of total units $/ \mathrm{kg} / 20$-min collection time. Weight was $1.56 \pm 0.03 \mathrm{~kg} 40$.

$\mathrm{ND}$, not determined. 
meals in healthy adults and in patients with CF $(32,61,64)$. Furthermore, as reported in healthy humans (65), an overall strong relationship was found between lipase and pepsin outputs independent of diet and time of sampling $\left(r^{2}=0.80 ; p<\right.$ 0.0001).

The gastric phase of lipolysis in CF patients supports the digestion of $20-36 \%$ of the TG ingested during $80 \mathrm{~min}$. These lipolysis rates are higher $[10 \%$ at $45 \mathrm{~min}$ after feeding (57)] or lower [33\% at 13 min (61)] than previously reported in CF patients. This discrepancy could be a result of differences in test meals or in study subjects. The nonlinear rates of gastric lipolysis can be explained by a feedback inhibition of gastric lipase activity by the progressive release of protonated fatty acids (31). This phenomenon has been shown to be dependent on the lipid surface area $(31,32)$. A fine emulsion sizing of approximately $0.7 \mu \mathrm{m}$ increases in size while in the human digestive tract with a consequent decrease in the surface area from 20.3 to $2.5-8.2 \mathrm{~m}^{2} / \mathrm{g}$ of fat (32). We can speculate that the test emulsions in this study had the same physicochemical pattern. Taking into account the total surface area of the emulsion, the fatty acid concentrations could have reached values shown previously to be inhibitory (32). Estimated total lipid surface areas during digestion were $23.5,12.8,11.8$, and $7.1 \mathrm{~m}^{2}$ and 26.3, 13.2, 9.0, and $5.3 \mathrm{~m}^{2}$ at 20, 40, 60 and $80 \mathrm{~min}$ during feeding of moderate-fat and high-fat diets, respectively. Thus, fatty acid concentrations reached $63,80,172$, and 248 or $87,164,185$, and $236 \mu \mathrm{mol} / \mathrm{m}^{2}$ surface at $20,40,60$, and 80 min after feeding moderate-fat and high-fat diets, respectively. In healthy humans, gastric lipolysis reaches a plateau for a concentration of $121-128 \mu \mathrm{mol} \mathrm{FFA} / \mathrm{m}^{2}$ (32). Inhibiting FFA concentrations were reached $60 \mathrm{~min}$ after feeding the moderate-fat test meal $(172 \mu \mathrm{mol})$ and $40 \mathrm{~min}$ after feeding the high-fat test meal $(164 \mu \mathrm{mol})$. This explains why lipolysis seems to stop more rapidly with the high-fat test meal; $22 \%$ lipolysis 40 min after feeding of the high-fat test meal (16 g of fat) led to the release of more fatty acid than a $24 \%$ lipolysis of the moderate-fat test meal ( $8.8 \mathrm{~g}$ of fat) $40 \mathrm{~min}$ after feeding. On the whole, the quantity of TG digested in the stomach is quite similar with the two diets, as it reached $3.2 \mathrm{~g} 80 \mathrm{~min}$ after feeding the moderate-fat test meal and $3.5 \mathrm{~g} 40 \mathrm{~min}$ after feeding the high-fat test meal. Once the duodenum is reached, this inhibition should be prevented by absorption of the fatty acids, which might allow lipolysis by gastric lipase to proceed, especially given the low $\mathrm{pH}$ in the upper small intestine in $\mathrm{CF}$ (18).

\section{CONCLUSIONS}

In conclusion, the data suggest that gastric lipase level is already high in children with CF who have a daily fat intake equal to or greater than $2 \mathrm{~g} / \mathrm{kg}$ body weight. A high-fat diet might benefit $\mathrm{CF}$ patients not only by providing higher energy and essential fatty acid intake but also by increasing the gastric lipase potential for fat digestion. As gastric lipase level is already high and does not increase further in the ranges of fat consumed by CF patients, the supplementation of exogenous recombinant gastric lipase might be the only way to increase the gastric lipase level and consequently gastric lipolysis. Fat digestion by gastric lipase could also be increased by feeding specific formulas with optimal physicochemical properties of the lipid emulsion.

Acknowledgments. The authors thank the patients who participated in this study and their parents for their enthusiasm.

\section{REFERENCES}

1. Ruzal-Shapiro C 1998 Cystic fibrosis. An overview. Radiol Clin North Am 36:143161

2. Kopelman H 1991 Cystic fibrosis: gastrointestinal and nutritional aspects. Thorax 46:261-267

3. Irons M 1993 Screening for metabolic disorders. How are we doing? Pediatr Clin North Am 40:1073-1085

4. Riordan JR, Rommens JM, Kerem BS 1989 Identification of the cystic fibrosis gene: cloning and characterization of complementary DNA. Science 245:1066-1073

5. Tizzano EF, Buchwald M 1992 Cystic fibrosis. Beyond gene to therapy. J Pediatr 120:337-349

6. Kerem E, Corey M, Kerem BS 1990 The relation between genotype and phenotype in cystic fibrosis - analysis of the most common mutation (DF508). N Engl J Med 323:1517-1522

7. Chase HP, Long MA, Lovin MH 1979 Cystic fibrosis and malnutrition. J Pediatr 95:337-345

8. di Sant'Agnese PA, Davis PB 1979 Cystic fibrosis in adults. Am J Med 66:121-132

9. Jacobs W, Kanarek J 1981 Cystic fibrosis: as they grow older. Am J Gastroenterol 76:343-346

10. Graham DY 1977 Enzyme replacement therapy of exocrine pancreatic insufficiency in man. N Engl J Med 296:1314-1317

11. DiMagno EP, Malagelada JR, Go VL, Moertel CG 1977 Fate of orally ingested enzymes in pancreatic insufficiency. Comparison of two dosage schedules. N Engl J Med 296:1318-1322

12. Walters MP, Littlewood JM 1996 Pancreatin preparations used in the treatment of cystic fibrosis: lipase content and in vitro release. Aliment Pharmacol Ther 10:433440

13. Ross CAC 1955 Fat absorption studies in the diagnosis and treatment of pancreatic fibrosis. Arch Dis Child 30:316-321

14. Lapey A, Kattwinkel J, di Sant'Agnese PA, Laster L 1974 Steatorrhea and azotorrhea and their relation to growth and nutrition in adolescents and young adults with cystic fibrosis. J Pediatr 84:328-334

15. Ross CAC, Sammons HG 1955 Nonpancreatic lipase in children with pancreatic fibrosis. Arch Dis Child 30:428-431

16. Abrams CK, Hamosh M, Lee TC, Ansher AF, Collen MJ, Lewis JH, Benjamin SB, Hamosh P 1988 Gastric lipase: localization in the human stomach. Gastroenterology 95:1460-1464

17. Hamosh M 1990 Lingual and Gastric Lipases: their Role in Fat Digestion. CRC Press, Boca Raton, FL, pp 239

18. Abrams CK, Hamosh M, Hubbard VS, Dutta SK, Hamosh P 1984 Lingual lipase in cystic fibrosis. Quantitation of enzyme activity in the upper small intestine of patients with exocrine pancreatic insufficiency. J Clin Invest 73:374-382

19. Dutta SK, Russell RM, Iber FL 1979 Impaired acid neutralization in duodenum in pancreatic insufficiency. Dig Dis Sci 24:775-780

20. Abrams CK, Hamosh M, Dutta SK, Hubbard VS, Hamosh P 1987 Role of nonpancreatic lipolytic activity in exocrine pancreatic insufficiency. Gastroenterology 92:125-129

21. Corey M, McLaughlin FJ, Williams M, Levison H 1988 A comparison of survival, growth, and pulmonary function in patients with cystic fibrosis in Boston and Toronto. J Clin Epidemiol 41:583-591

22. Hubbard VS 1982 Energy intake and nutrition counselling in CF. J Am Diet Assoc 80:127-131

23. MacDonald A, Holden C, Harris G 1991 Nutritional strategies in cystic fibrosis: current issues. J Roy Soc Med 84:28-35

24. Hamosh M 1978 Rat lingual lipase: factors affecting enzyme activity and secretion Am J Physiol 235:E416-E421

25. Armand M, Borel P, Cara L, Senft M, Chautan M, Lafont H, Lairon D 1990 Adaptation of lingual lipase to dietary fat in rats. J Nutr 120:1148-1156

26. Borel P, Armand M, Senft M, André M, Lafont H, Lairon D 1991 Gastric lipase: evidence of an adaptive response to dietary fat in the rabbit. Gastroenterology 100:1582-1589

27. Armand M, Borel P, Rolland PH, Senft M, André M, Lafont H, Lairon D 1992 Adaptation of gastric lipase in mini-pigs fed a high-fat diet. Nutr Res 12:489-499

28. Armand M, Hamosh M, DiPalma JS, Gallagher J, Benjamin SB, Philpott JR, Lairon D, Hamosh P 1995 Dietary fat modulates gastric lipase activity in healthy humans. Am J Clin Nutr 62:74-80

29. Taussig LM, Kattwinkel J, Friedwald WT, di Sant' Agnese PA 1973 A new prognostic score and clinical evaluation system for cystic fibrosis. J Pediatr 82:380 390

30. Tomezsko JL, Scanlin TF, Stallings VA 1994 Body composition of children with cystic fibrosis with mild clinical manifestations compared with normal children. Am J Clin Nutr 59:123-128

31. Pafumi Y, Lairon D, Lechene De La Porte P, Juhel C, Storch J, Hamosh M, Armand M 2002 Mechanisms of inhibition of triacylglycerol hydrolysis by human gastric lipase. J Biol Chem 277:28070-28079 
32. Armand M, Pasquier B, André M, Borel P, Senft M, Peyrot J, Salducci J, Portugal H, Jaussan V, Lairon D 1999 Digestion and absorption of two fat emulsions with different droplet sizes in the human digestive tract. Am J Clin Nutr 70:1096-1106

33. Hernell O, Staggers JE, Carey MC 1990 Physico-chemical behavior of dietary and biliary lipids during intestinal digestion and absorption. 2. Phase analysis and aggregation states of luminal lipids during duodenal fat digestion in healthy adult human beings. Biochemistry 29:2041-2056

34. Armand M, Borel P, Pasquier B, Dubois C, Senft M, André M, Peyrot J, Salducci J, Lairon D 1996 Physicochemical characteristics of emulsions during fat digestion in human stomach and duodenum. Am J Physiol 34:G172-G183

35. Carrière F, Laugier R, Barrowman JA, Douchet I, Priymenko N 1993 Gastric and pancreatic lipase levels during a test meal in dogs. Scand J Gastroenterol 28:443-454

36. Hamosh M, Scanlon JW, Ganot D, Likel M, Scanlon KB, Hamosh P 1981 Fat digestion in the newborn: characterization of lipase in gastric aspirates of premature and term infants. J Clin Invest 67:838-846

37. George JD 1968 New clinical method for measuring the rate of gastric emptying: the double sampling test meal. Gut 9:237-242

38. Cortot A, Phillips SF, Malagelada JR 1979 Gastric emptying of lipids after ingestion of homogenized meal. Gastroenterology 76:939-944

39. Meyer JH, Mayer EA, Jehn D, Gu YG, Fried M, Fink AS 1986 Gastric processing and emptying of fat. Gastroenterology 90:1176-1187

40. Armand M, Hamosh M, Mehta NR, Angelus PA, Philpott JR, Henderson TR, Dwyer NK, Lairon D, Hamosh P 1996 Effect of human milk or formula on gastric function and fat digestion in the premature infant. Pediatr Res 40:429-437

41. Belfrage P, Vaughan M 1969 Simple liquid-liquid partition system for isolation of labeled oleic acid from mixtures with glycerides. J Lipid Res 10:341-344

42. Vavrikova H, Krondl A 1965 Use of polyethylene glycol in investigations of the absorption of fat. Nature 208:293-294

43. Anson ML, Mirsky AE 1932 The estimation of pepsin with hemoglobin. J Gen Physiol 16:59-63

44. Schlamowitz M, Petersen LV 1955 Studies on the optimum $\mathrm{pH}$ for the action of pepsin in "native" and denaturated bovine serum albumin and bovine hemoglobin. J Biol Chem 217:193-198

45. Folch JM, Lees M, Stanley JHG 1957 A simple method for the isolation and purification of total lipids from animal tissue. J Biol Chem 226:498-509

46. Bitman J, Wood LD 1981 Quantitative densitometry in situ of lipids separated by thin layer chromatography. J Liq Chromatogr 4:1023-1034

47. Hyden S 1955 A turbidimetric method for the determination of higher polyethylene glycols in biological materials. Kungl Lantbrukshogskolans Annaler 22:139-140

48. Ulyatt M 1964 The use of polyethylene glycol as a marker for measuring rumen water volume and the rate of flow of water from the rumen of grazing sheep. $\mathrm{N} \mathrm{Z} \mathrm{J} \mathrm{Agric}$ Res 76:713-722

49. Winer BJ 1971 Statistical Principles in Experimental Design. McGraw-Hill, New York, pp 261-308
50. Hamosh M, Hamosh P 1966 Selectivity of lipases: developmental aspects. In: Malcata FX (ed) Engineering of/with Lipases. NATO ASI Series E Applied Sciences. Kluwer Academic Publishers, Dardrecht, pp 31-49

51. FitzSimmons SC, Burkhart GA, Borowitz D, Grand RJ, Hammerstrom T, Durie PR, Lloyd-Still JD, Lowenfels AB 1997 High-dose pancreatic-enzyme supplements and fibrosing colonopathy in children with cystic fibrosis. N Engl J Med 336:1283-1289

52. Kawchak DA, Zhao H, Scanlin TF, Tomezsko JL, Cnaan A, Stallings VA 1996 Longitudinal, prospective analysis of dietary intake in children with cystic fibrosis. J Pediatr 129:119-129

53. Tomezsko JL, Stallings VA, Scanlin TF 1992 Dietary intake of healthy children with cystic fibrosis compared with normal control children. Pediatrics 90:547-553

54. Stark LJ, Jelalian E, Mulvihill MM, Powers SW, Bowen AM, Spieth LE, Keating K, Evans S, Creveling S, Harwood I, Passero MA, Hovell MF 1995 Eating in preschool children with cystic fibrosis and healthy peers: behavioral analysis. Pediatrics 95:210-215

55. Kindstedt-Arfwidson K, Strandvik B 1988 Food intake in patients with cystic fibrosis on an ordinary diet. Scand J Gastroenterol Suppl 143:160-162

56. Daniels L, Davidson GP, Cooper DM 1987 Assessment of nutrient intake of patients with cystic fibrosis compared with healthy children. Hum Nutr Appl Nutr 41:151-159

57. Balasubramanian K, Zentler-Munro PL, Batten JC, Northfield TC 1992 Increased intragastric acid resistant lipase activity and lipolysis in pancreatic steatorrhea due to cystic fibrosis. Pancreas 7:305-310

58. Weisselberg B, Yahav J, Reichman B, Jones A 1992 Basal and meal-stimulated pepsinogen secretion in premature infants. J Pediatr 110:949-951

59. DiPalma JS, Kirk CL, Hamosh M, Colon AR, Benjamin SB, Hamosh P 1991 Lipase and pepsin activity in the gastric mucosa of infants, children, and adults. Gastroenterology 101:116-121

60. Frederikzon B, Blackberg L 1980 Lingual lipase: an important enzyme in the digestion of dietary lipids in cystic fibrosis? Pediatr Res 14:1387-1390

61. Roulet M, Weber AM, Paradis Y, Roy CC, Chartrand L, Lasalle R, Morin CL 1980 Gastric emptying and lingual lipase activity in cystic fibrosis. Pediatr Res 14:13601367

62. Moreau H, Sauniere JF, Gargouri Y, Pieroni G, Verger R 1988 Human gastric lipase: variations induced by gastrointestinal hormones and by pathology. Scand J Gastroenterol 23:1044-1049

63. Lloyd-Still JD, Smith AE, Wessel HU 1989 Fat intake is low in cystic fibrosis despite unrestricted dietary practices. JPEN J Parenter Enteral Nutr 13:296-298

64. Gregory PC Gastrointestinal $\mathrm{pH}$, motility/transit and permeability in cystic fibrosis 1996 J Pediatr Gastroenterol Nutr 23:513-523

65. Szafran Z, Szafran H, Popiela T, Trompeter G 1978 Coupled secretion of gastric lipase and pepsin in man following pentagastrin stimulation. Digestion 18:310318 